8. Centers for Disease Control. Methicillin-resistant Staphylococcus aureusUnited States. MMWR1981;30:140-147.

9. Preheim LC, Rimland D, Bittner MJ. Methicillin-resistant Staphylococcus aureus in Veterans Administration Medical Centers. Infect Control 1987;8:191-194.

10. Panlilio AL, Culver DH, Gaynes RP, et al. Methicillin-resistant Staphylococcus aureus in US hospitals, 1971-1991. Infect Control Hosp Epidemiol 1992:13:582-586.

11. Boyce J. Methicillin-resistant Staphylococcus aureus: detection, epidemiology and control measures. Infect Dis Clin North Am 1989;3:901-913.

12. Locksley RM, Cohen ML, Quinn TC, et al. Multiply antibiotic-resistant Staphylococcus aureus: introduction, transmission, and evolution of nosocomial infections. Ann Intern Med 1982;97:317-324.

13. Farrington M, Ling J, Ling T, French GL. Outbreaks of infection with methicillin-resistant Staphylococcus aureus on neonatal and burn units of a new hospital. Epidemiol Infect 1990;105:215-228.

14. Hambreus A. Studies on transmission of Staphylococcus aureus in an isolation ward for burned patients. J Hyg Epidemiol Microbiol Immunol 1973;71:171-183.

15. Crossley K, Landesman B, Zaske D. An outbreak of infection caused by strains of Staphylococcus aureus resistant to methicillin and aminoglycosides, II: epidemiologic studies. J lnfect Dis 1979;139:280-287.

16. Boyce JM, Landry M, Deetz TR, Dupont HL. Epidemiologic studies of an outbreak of nosocomial methicillin-resistant Staphylococcus aureus infections. Infect Control 1981;2:11-116.

17. Boyce JM, White RL, Causey WA, Lockwood WR. Burn units as a source of methicillin-resistant Staphylococcus aureus infection. JAMA 1983;249:2083 2087.

18. Arnow PM, Allyn PA, Nichols EM, Hill DL, Pezzlo M, Bartlett RH. Control of methicillin-resistant Staphylococcus aureus in a burn unit: role of nurse staffing. JTrauma 1982;22:954-959.

19. Linnemann CC Jr, Mason M, Moore P, Korfhagen TR, Staneck JL. Methicillin-resistant Staphylococcus aureus experience in a general hospital over four years. Am J Epidemiol 1982;115:941-950.

20. Everett ED, McNitt TR, Rahm AE, et al. Epidemiologic investigation of methicillin-resistant Staphylococcus aureus in a burn unit. Mil Med 1978;143:165-167.

21. Saraglou G. Cromer M, Bisno AL. Methicillin-resistant Staphylococcus aureus; interstate spread of nosocomial infections with emergence of gentamycin-methicillin resistant strains. Infect Control 1980;1:81-87.

22. Atsumi N. MRSA infections in multiple trauma patients. Nippon Rinsho 1992;50:1099-1103.

23. Craven DE, Reed C, Kollisch N, et al. A large outbreak of infections caused by a strain of Staphylococcus aureus resistant to oxacillin and aminoglycosides. Am J Med 1981; 71:53-58.

24. Klimek JJ, Marsik FJ, Bartlett RC, Wier B, Shea P, Quintiliani R. Clinical, epidemiologic and bacteriologic observations of an outbreak of methicillinresistant Staphylococcus aureus at a large community hospital. Am J Med 1976;61:340-345.

25. Peacocok JE Jr, Marisk FJ, Wenzel RP. Methicillin-resistant Staphylococcus aureus: introduction and spread within a hospital. Ann Intern Med 1980;93:526-532.

26. Alvarez S, Shell C, Gage K, et al. An outbreak of methicillin-resistant Staphylococcus aureus eradicated from a large teaching hospital. Am J Infect Control 1985;13:115-121.

27. Thompson RL, Cabezudo I, Wenzel RP Epidemiology of nosocomial infections caused by methicillin-resistant Staphylococcus aureus. Ann Intern Med 1982;97:309-317.

\title{
OSHA Updates Guidelines on Hazardous Drug Exposures
}

\section{by Gina Pugliese, RN, MS Medical News Editor}

A chapter supplying compliance inspectors with updated information on controlling occupational exposure to hazardous drugs will be added to the Occupational Safety and Health Administration's (OSHA) technical manual for inspectors (OSHA Instruction CPL2-2.20B CH-4). The manual is designed to provide relevant information to OSHA inspectors when they are conducting investigations.

Responding to numerous inquiries, OSHA published guidelines in 1986 for the management of cytotoxic (antineoplastic) drugs in the workplace. Numerous requests for more information on the subject prompted OSHA to revise the 1986 guidelines and to expand them to cover hazardous drugs. The document cites recommendations from the American Society of Healthcare Pharmacists' guidelines on hazardous drugs. These include criteria for classifying drugs as hazardous; evidence supporting the management of hazardous drugs as an occupational hazard; development of standard operating procedures and identification of a person responsible for implementing a plan; recommended protective equipment and worker education; medical surveil- lance; and hazardous drugs in common use. Anesthetic agents are addressed elsewhere in the technical manual. According to an April 14, 1995, instruction signed by OSHA Administrator Joseph A. Dear, the guidelines apply to all settings where employees are exposed: hospitals, physicians' offices, and home healthcare agencies. OSHA recommends that healthcare employers implement the new guidelines.

FROM: Bureau of National Affairs. Hazardous drug exposure guidelines issued by OSHA. Health Care Facilities Guide N ewsletter May 9 , 1995. 